\title{
ЗАСТОСУВАННЯ АПАРАТНО-ПРОГРАМНИХ КОМПЛЕКСІВ У РЕАБІЛІТАЦІї ХВОРИХ ІЗ ВЕРТЕБРОГЕННИМИ ЗАХВОРЮВАННЯМИ
}

\author{
О. А. Панченко, С. М. Радченко, В. Г. Антонов, А. В. Зарубайко \\ ДЗ “Науково-практичний медичний реабілітаційно-діагностичний центр МОЗ України"
}

\begin{abstract}
Розглянуто сучасні аспекти реабілітації хворих із патологією опорно-рухової системи із застосуванням апаратнопрограмних комплексів. Проаналізовано отримані результати при використанні реабілітаційних програм із застосуванням кінезіотерапії у хворих із вертеброгенними захворюваннями. Зроблено висновок про ефективність комплексів даного класу та рекомендовано більш широке їх застосування.
\end{abstract}

Ключові слова: реабілітація, кінезіотерапія, інформатизація, реабілітаційне обладнання, апаратно-програмний комплекс.

\section{ПРИМЕНЕНИЕ АППАРАТНО-ПРОГРАММНЫХ КОМПЛЕКСОВ С ОБРАТНОЙ СВЯЗЬЮ В РЕАБИЛИТАЦИИ БОЛЬНЫХ С ВЕРТЕБРОГЕННЫМИ ЗАБОЛЕВАНИЯМИ}

\author{
О. А. Панченко, С. М. Радченко, В. Г. Антонов, А. В. Зарубайко \\ ГУ "Научно-практический медицинский реабилитационно-диагностический центр \\ МЗ украины"
}

\begin{abstract}
Рассмотрены современные аспекты реабилитации больных с патологией опорно-двигательной системы с использованием аппаратно-программных комплексов. Проанализированы полученные результаты использования реабилитационных программ с использованием кинезиотерапии у больных с вертеброгенной патологией. Сделан вывод об эффективности комплексов данного класса и рекомендовано более широкое их использование.
\end{abstract}

Ключевые слова: реабилитация, кинезиотерапия, информатизация, реабилитационное оборудование, аппаратно-программный комплекс.

\section{APPLICATION OF THE HARDWARE-SOFTWARE BIOFEEDBACK COMPLEXES IN THE REHABILITATION OF PATIENTS WITH VERTEBROLOGY PATHOLOGY}

\author{
O. A. Panchenko, S. M. Radchenko, V. H. Antonov, A. V. Zarubaiko \\ SI "Scientific-Practical Medical Rehabilitation-Diagnostic Centre of MPH of Ukraine"
}

\begin{abstract}
The modern aspects of the rehabilitation of patients with pathology of musculoskeletal system with use hardware-software biofeedback complexes are considered. The results of the use of the rehabilitation programs with the application of kinesiotherapy for patients with vertebrogenic pathology are analyzed. A conclusion about efficiency of complexes of this class is done and their more wide use is recommended.
\end{abstract}

Key words: rehabilitation, kinesiotherapy, informatization, rehabilitation equipment, hardware-software complex.

Вступ. Сучасна реабілітація відрізняється високим рівнем інформатизації діагностичних і лікувальних методик, впровадженням нових засобів діагностики і направленого зовнішнього впливу на організм (реабілітаційне устаткування, апаратно-програмні комплекси), що базуються на передових технологіях кібернетики, мікропроцесорної техніки, програмування тощо. В усіх цих системах на першому місці стоять завдання точного дозування параметрів роботи, стабільного утримання їх заданих значень в умовах мінливості фізіологічних характеристик організму паціента.

Особливої уваги заслуговують комплекси з біологічним зворотним зв'язком, робота яких направлена на розвиток та вдосконалення механізмів саморегуляції фізіологічних функцій при різних патологічних

(C) О. А. Панченко, С. М. Радченко, В. Г. Антонов, А. В. Зарубайко 
станах. Поки що такі комплекси в реабілітаційних закладах України застосовуються мало, тому досвід роботи з ними та доведення на практиці їх ефективності мають велике значення для популяризації цього безперечно перспективного методу реабілітації.

Мета роботи - дослідження ефективності реабілітації хворих із вертеброгенними захворюваннями iз застосуванням багатофункціонального апаратнопрограмного комплексу EN-TreeM.

Матеріали та методи. У дослідженні ефективності застосування реабілітаційних програм у лікуванні захворювань опорно-рухової системи брали участь 269 осіб - 73 чоловіки та 196 жінок (табл. 1), які перебували на відновлювальному лікуванні в Д3 «НПМ РДЦ МО3 України», з вертеброгенними порушеннями (М 42.0-M 54 за МКБ-10) в ступені загострення. Водночас із лікуванням за клінічним протоколом надання медичної допомоги на дорсопатію (наказ МО3 України від 17.08.2007 р. № 487) хворим було запропоновано реабілітаційне лікування за оригінальною методикою із застосуванням багатофункціонального апаратно-програмного комплексу ENTreeM.

Таблиця 1. Характеристика обстежуваного контингенту

\begin{tabular}{|c|c|c|c|}
\hline Стать & $\begin{array}{c}\text { Вік, років } \\
(\mathrm{M} \pm \mathrm{m})\end{array}$ & $\begin{array}{c}\text { Кількість } \\
\text { обстежених }\end{array}$ & $\begin{array}{c}\text { Кількість } \\
\text { сеансів } \\
\text { реабілітації }\end{array}$ \\
\hline Чоловіки & $53 \pm 1,8$ & 73 & 1656 \\
\hline Жінки & $52 \pm 1,6$ & 196 & 2461 \\
\hline \multicolumn{2}{|c|}{ Загальна кількість } & 269 & 4117 \\
\hline
\end{tabular}

Зовнішній огляд, опитування пацієнтів на наявність скарг на поточний стан здоров' я та аналіз їх амбулаторних карт надали можливість виділити осіб із дорсопатіями (178 осіб, середній вік $(51 \pm 1,7)$ рік) та плексопатіями (91 особа, середній вік - $(55 \pm 1,6)$ років). Характеристика досліджуваного контингенту представлена в таблиці 2 .

Таблиця 2. Характеристика контингенту, розподіленого за діагнозом

\begin{tabular}{|c|c|c|c|}
\hline $\begin{array}{c}\text { Діагноз } \\
\text { осіб }\end{array}$ & $\begin{array}{c}\text { Вік, } \\
\text { років } \\
(\mathrm{M} \pm \mathrm{m})\end{array}$ & $\begin{array}{c}\text { Кількість } \\
\text { обстежених }\end{array}$ & $\begin{array}{c}\text { Кількість } \\
\text { сеансів } \\
\text { реабілітації }\end{array}$ \\
\hline Дорсопатії & $51 \pm 1,7$ & 178 & 3134 \\
\hline Плексопатії & $55 \pm 1,6$ & 91 & 983 \\
\hline \multicolumn{2}{|c|}{ Загальна кількість } & 269 & 4117 \\
\hline
\end{tabular}

У пацієнтів із дорсопатіями домінували больовий i м'язовотонічний синдроми, а у осіб із плексопатія- ми, крім вищезазначених, виявлявся корінцевий синдром. Пацієнти скаржилися на біль в попереку, обмеження рухів, які посилювалися при поворотах тулуба, напруження м'язів. Пацієнти обох груп проходили стандартне лікування, яке включало нестероїдну протизапальну, вітамінотерапію, міорелаксаційну, хондропротекторну терапію.

Для оцінки стану організму пацієнтів до початку i після курсу лікування проводилися наступні методи: збір анамнезу, об'єктивне дослідження, антропометричні дані.

Оцінка стану нервово-м'язового апарату проводилася за даними електроміографії (EMГ) до та після курсу кінезіотерапії за допомогою апарата «MYOMED 932».

Застосовували такі методи дослідження: дослідження іннервації; проба на збудливість; визначення реобази, хронаксії, величини корисного часу по кривій $1 / t$.

Об'єктом дослідження при міографії були м'язи передпліччя правої і лівої рук, круглий пронатор (M. pronator teres), що пронує передпліччя і бере участь в його згинанні. Інервується N. Medianus від С6-С7.

Для дослідження іннервації проводили порівняння реакції двох симетричних контрлатеральних м'язів або груп м'язів, в одній з яких іннервація, імовірно, порушена.

При проведенні проби на збудливість визначали міру дегенерації в м'язах. Для цього проводили стимуляцію м'яза і визначали його відповідь на подразнення. У ході міографічного дослідження визначали реобазу, хронаксію, по кривій l/t визначали величину корисного часу.

Всього було проведено 538 досліджень хронаксіі.

Кінезіотерапія - один із головних режимів роботи тренажера EN-TreeM, проводилася із застосуванням біологічного зворотного зв'язку. Біологічний зворотний зв' язок - технологія, яка включає комплекс дослідницьких, лікувальних і профілактичних фізіологічних процедур, у ході яких пацієнтові за допомогою зовнішнього ланцюга зворотного зв'язку, організованого переважно за допомогою мікропроцесорної або комп'ютерної техніки, пред'являється інформація про стан і зміну тих або інших власних фізіологічних процесів. Терапія за цією технологією полягає в безперервному моніторингу в режимі реального часу певних фізіологічних показників і свідомому управлінні ними за допомогою мультимедійних, ігрових та інших прийомів в заданому діапазоні значень. Для стимулювання пацієнта в процесі тренувальної терапії й реабілітації вибирались різні 
екранні сторінки зворотного зв'язку, оптимальні з точки зору пацієнта.

Отримані результати аналізувалися в статистичних пакетах Statistica 5.5, Statistica Neural Networks 4.0 C, MedStat 2004.

Результати та їх обговорення. У результаті досліджень встановлено, що вихідні значення сили і витривалості у чоловіків і жінок достовірно відрізнялися $(\mathrm{p}<0,05)$. У жінок початкове середне значення сили складало $(22,0 \pm 0,9)(95 \%$ BI 20-24) кгс, у чоловіків - $(44,0 \pm 1,5)(95 \%$ ВI 40-46) кгс. М'язова витривалість у жінок до курсу складала в середньому $(32,5 \pm 2,9)$ (95\% ВI 30-40) с, у чоловіків - $(45,0 \pm 4,1)(95 \%$ ВI 45-50) с (табл. 3).

Таблиця 3. М'язова сила та м'язова витривалість у 1-й день реабілітації, $\mathrm{M} \pm \mathrm{m}$

\begin{tabular}{|c|c|c|}
\hline Дослідження & $\begin{array}{c}\text { Чоловіки, } \\
\mathrm{n}=73\end{array}$ & $\begin{array}{c}\text { Жінки, } \\
\mathrm{n}=196\end{array}$ \\
\hline М'язова сила, кгс & $44,0 \pm 1,5$ & $22,0 \pm 0,9$ \\
\hline М'язова витривалість, с & $45,0 \pm 4,1$ & $32,5 \pm 2,7$ \\
\hline
\end{tabular}

Вплив разового сеансу кінезіотерапії характеризувався збілышенням м'язової сили і витривалості у пацієнтів обох статей. Значення сили як у жінок, так і у чоловіків збільшувалися в середньому на 1 (95\% BI 0-2) кгс (p<0,05). М'язова витривалість у жінок змінювалася в середньому на 2 (95\% ВI 1-3) с, у чоловіків на $1(95 \%$ ВI $0-4)$ с $(\mathrm{p}<0,05)$. Ці зміни говорять про стимулювальний вплив кінезіотерапії на організм людини, який покрашує функціональний стан нервово-м'язового апарату.

Впливу всього курсу реабілітації на значення показників сили у жінок виявлено не було, у чоловіків сила збільшилась в середньому до 45,5 $\pm 2,7$ ( $p>0,05)$ (табл. 4).

Таблиця 4. М'язова сила та м'язова витривалість на 20-йдень реабілітації, $\mathrm{M} \pm \mathrm{m}$

\begin{tabular}{|c|c|c|}
\hline Дослідження & $\begin{array}{c}\text { Чоловіки, } \\
\mathrm{n}=73\end{array}$ & $\begin{array}{c}\text { Жінки, } \\
\mathrm{n}=196\end{array}$ \\
\hline М'язова сила, кгс & $45,5 \pm 2,7$ & $22,5 \pm 0,9$ \\
\hline М'язова витривалість, с & $50,0 \pm 1,7$ & $33,2 \pm 1,6$ \\
\hline
\end{tabular}

Після курсу реабілітації у чоловіків витривалість збільшилася в середньому на 5 (95\% ДІ 2-6) с і складала $(50 \pm 1,7)(95 \%$ ВI 49-55) с $(\mathrm{p}<0,05)$, у жінок витривалість практично залишилася на колишньому рівні $(33,2 \pm 1,6)(95 \%$ BI 36-47) с $(\mathrm{p}>0,05)$.

У процесі дослідження було проведено дослідження хронаксії. Вихідні значення хронаксії у жінок скла-

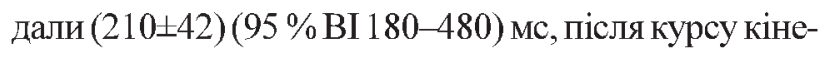
зіотерапіі-(212 \pm 46$)(95 \%$ BI 150-400) мс, ці значення статистично між собою не відрізнялися $(\mathrm{p}>0,05)$ (табл. 5).

Таблиця 5. Динаміка показників хронаксії в результаті курсу реабілітації, $\mathrm{M} \pm \mathrm{m}$

\begin{tabular}{|c|c|c|}
\hline \multirow{2}{*}{ Дні реабілітації } & \multicolumn{2}{|c|}{ Хронаксія, мс } \\
\cline { 2 - 3 } & чоловіки, $\mathbf{n}=73$ & жінки, $\mathbf{n}=196$ \\
\hline 1 день & $200 \pm 35$ & $210 \pm 42$ \\
\hline 20 день & $130 \pm 61$ & $200 \pm 46$ \\
\hline
\end{tabular}

У чоловіків середнє значення хронаксії до курсу кінезіотерапії було зафіксоване на рівні $(200 \pm 35)(95 \%$ ДI 150-280) мс, після курсу воно складало (130ـ61) (95\% ДI 100-300) мс ( $<<0,05)$. Таким чином, курс реабілітації впливав на показники лише у чоловіків.

Клінічні спостереження продемонстрували хорошу переносимість кінезіотерапії та відсутність негативних реакцій. Всі хворі відзначали зменшення вихідного болю і легше виконували фізичні вправи. Поліпшення наставало вже після перших процедур.

Після курсу реабілітації спостерігалося значуще зниження болю, запалення аж до повного купірування больового синдрому і деструктивних запальних реакцій, збільшення об'єму рухів. Термін купірування вертеброгенного больового синдрому склав 2-5 днів, корінцевого - 4-12 днів. Оцінка інтенсивності болю здійснювалась 3 використанням Verbal Descriptor Scale-VDS (Gaston-Johansson F.,Albert M., Fagan E. [et al.], 1990) до та після закінчення курсу реабілітаціі. Виявлено статистично значуще зниження больовому синдрому (p<0,05) (табл. 6).

Таблиця 6. Динаміка середніх показників інтенсивності болю за шкалою VDS, $\mathrm{M} \pm \mathrm{m}$

\begin{tabular}{|c|c|c|}
\hline \multirow{2}{*}{$\begin{array}{c}\text { Дні } \\
\text { кінезіотерапії }\end{array}$} & \multicolumn{2}{|c|}{ Інтенсивність болю, бали } \\
\hline 1-й день & $4,6 \pm \mathbf{1 , 6}$ & $4,2 \pm 1,0$ \\
\hline 20 -й день & $2,1 \pm \mathbf{0 , 8}$ & $\mathbf{1 , 8} \pm 0,4$ \\
\hline
\end{tabular}

3 клінічних проявів на 1-й день кінезіотерапії у пацієнтів мали місце: больовий синдром - у 260 осіб (97\%), оніміння тильної поверхні стопи -у 182 осіб $(67,5 \%)$, слабкість розгинання 1 пальця стопи - у 60 осіб $(22,5 \%)$, кульгавість - у 54 осіб (20\%), зниження ахілових рефлексів - у 25 осіб $(9 \%)$.

Критеріями якості лікування хворих із патологією опорно-рухового апарату стали:

1. Зменшення або зникнення больового синдрому.

2. Зменшення або зникнення корінцевих проявів. 
3. Збільшення обсягу рухів в ураженому відділі.

4. Покращення самопочуття.

5. Клінічне одужання або поліпшення.

В результаті проведеного лікування всі $100 \%$ пацієнтів 3 дорсопатіями та плексопатіями були виписані з поліпшенням. Спостерігалось помітне зменшення больового синдрому, зникли прояви оніміння тильної поверхні стопи, слабкості розгинання 1 пальця стопи, кульгавість, знизились ахілові рефлекси $(\mathrm{p}<0,05)$.

Випадків погіршення стану хворих в процесі лікування не відмічено, побічних ефектів і ускладнень при проведенні процедур не спостерігалося.

Висновки. 1. Вплив окремо взятого сеансу кінезіотерапії у хворих із вертеброгенною патологією характеризувався збільшенням м'язової сили і витривалості у пацієнтів обох статей. Це свідчить про стимулювальний вплив сеансу кінезіотерапії на організм людини, який покрапує функціональний стан нервово-м'язового апарату. Значення сили й у жінок, і у чоловіків в результаті сеансу кінезіотерапії збільшувалися в середньому на 1 (95\% ВI 0; 2) кгс $(\mathrm{p}<0,05)$; м'язова витривалість у жінок змінювалася в середньому на 2 (95 \% ВI 1; 3) с, у чоловіків - на 1 (95\% ВI $0 ; 4)$ c $(\mathrm{p}<0,05)$. Після курсу реабілітації виявлено збільшення м'язової витривалості у чоловіків в середньому на 4 (95\% ДІ 2; 6) с, у жінок статистично

\section{Література}

1. Биоуправление в клинической практике / М. Б. Штарк, С. С. Павленко, А. Б. Скок, О. С. Шубина // Неврологічний журнал - 2000. - № 5. - С. 52-56.

2. Мінеер О. П. Проблеми виявленшя нових знань із сховищ медичних даних. Перше повідомлення / О. П. Мінцер, С. В. Денисенко, Л. Ю. Бабінцева // Медична інформатика та інженерія. - 2012. - № 2. - С. 5-10.

3. Информатизация реабилитационно-диагностического процесса в современных медицинских учреждениях / О. А. Панченко, А. Н. Пономаренко, А. Е. Горбань [и др.] // Реабилитациия и абилитация человека. Клиническая информационная проблематика : сб. научн. работ / под общ. ред. проф. О. А. Панченко. -К. : КВИЦ, 2012.-- С. 175-189. 4. Соколов А. В. Современные направления и перспективы развития аппаратных средств биоуправления/ достовірних відмінностей параметрів витривалості до і після курсу зафіксовано не було.

2. Міографічні дослідження показали, що значення хронаксії в результаті курсу кінезіотерапії у жінок залишалися стабільними, а у чоловіків змінювалися на (70土16) $(95 \%$ ВІ 60; 123) мс. Це свідчить про лабільність м'язового тонусу у чоловіків, обумовлену високою питомою вагою поперечносмугастих м'язів.

3. Клінічні спостереження продемонстрували хорошу переносимість процедур кінезіотерапії і відсутність негативних реакцій. Всі хворі відзначали зменшення вихідного болю і полегшення виконання фізичних вправ. Поліпшення наставало вже після перших процедур. Після курсу реабілітації спостерігалося значуще зниження болю та запалення аж до повного купірування больового синдрому і деструктивних запальних реакцій, збільшення об'єму рухів. Термін купірування вертеброгенного больового синдрому склав 2-5 днів, корінцевого -4-12 днів.

4. Використання програмно-апаратних комплексів в реабілітації хворих з вертеброгенною патологією дозволяє досягнути ії високої ефективності. Представляс інтерес подальше дослідження ефективності застосування даного класу комплексів у реабілітації хворих з іншими патологіями.

А. В. Соколов // Медицинская техника. - 2007. - № 4. C. $39-41$.

5. Основы компьютерной биостатистики: анализ информации в биологии, медицине и фармации статистическим пакетом «MedStat» / Ю. Е. Лях, В. Г. Гурьянов, В. Н. Хоменко, О. А. Панченко. - Д. : Папакица Е. К., 2006.-214 с. 6. Glinkowski W. Musculoskeletal 3G telerehabilitation / W. Glinkowski, M. Wasilewska, M. Gil [et al.]//Ukr. z. telemed. med. telemat.-2007.-Vol. 5, № 2.-P. 189-190.

7. Web-Based Telerehabilitation for the Upper Extremity After Stroke / D. Reinkensmeyer, C. Pang, J. Nessler, C. Painter // IEEE Transactions on Neural Systems and Rehabilitation Engineering. - 2002.-Vol. 10, № 2.-P. 102-108. 